\title{
ОСНОВНЫЕ ЧЕРТЫ МЕДИЙНОГО ОБРАЗА ДОНАЛЬДА ТРАМПА (НА МАТЕРИАЛАХ НЕМЕЦКИХ СМИ)
}

Мищуткина Ирина Игоревна

Кандидат филологических наук, дочент, дочент кафедры иностранных языков и методики преподавания, Федеральное государственное бюджетное образовательное учреждение высшего образования «Хакасский Государственный Университет им. Н.Ф. Катанова», 655017, Республика Хакасия, г. Абакан, ул. Ленина, 90.

\section{MAIN FEATURES OF THE MEDIA IMAGE OF DONALD TRUMP (ON MATERIALS OF THE GERMAN MEDIA)}

Irina Mishutkina

PhD in Philology, Associate Professor, Department of Foreign Languages and Teaching Methods,

Federal State-Funded Educational Institution of Higher Education "Khakass State University named after N.F. Katanov", 655017, Republic of Khakasia, Abakan, Lenin

Prospect, 90.

\section{АННОТАЦИЯ}

В статье представлен анализ немецких медийных текстов, посвященных Дональду Трампу. В результате проведенного анализа были выявлены основные черты образа американского президента, сформированного в немецкой прессе, а также определены некоторые закономерности их проявления.

Ключевые слова: лексема, медийный образ, медийный текст, средства массовой информации, смысл.

\section{ABSTRACT}

The article presents an analysis of German media texts devoted to Donald Trump. As a result of the analysis, the main features of the image of the American President, formed in the German press, as well as some patterns of their manifestation were identified.

Key words: lexeme, media image, media text, mass media, meaning. 
Современное общество характеризуется крайней политизированностью, так как проблемы в социальной, бытовой и других сферах являются острыми и злободневными и активно обсуждаются в средствах массовой информации. Интерес к политической жизни находит свое отражение и в тематике лингвистических исследований [1], обусловливая актуальность изучения дискурса масс-медиа, который определяется как «...любой материал в средствах массовой информации, в котором речь идет о политике, автором которого является политик или, наоборот, адресованный политику», и входит, таким образом, в поле политического дискурса [5, с. 129 - со ссылкой на Е.И. Шейгал].

Основная цель политической коммуникации - борьба за власть. Следует заметить, что за власть борются не только политики, но и средства массовой информации ведут борьбу за умы людей, формируя тот или иной образ политического деятеля в общественном сознании.

Материалом настоящего исследования послужили тексты немецких периодических изданий за первые шесть месяцев 2019 года [6,7,8,9]. Цель работы - выявить основные черты медийного образа Дональда Трампа, формируемого немецкими авторитетными средствами массовой информации. После избрания президентом Дональд Трамп стал объектом достаточно большого количества лингвистических работ $[2,3,4]$.

Анализ языкового материала показывает, что образ Дональда Трампа в немецких СМИ неоднозначен. Он наделен и положительными, и отрицательными качествами, часто балансирует на грани «хорошее-плохое», не оставляя немецких журналистов равнодушными.

\section{Отрицательные черты.}

Для действий Дональда Трампа немецкие журналисты очень часто выбирают глаголы «drohen» - «угрожать», «attackieren» - «атаковать». Тем самым они создают образ американского президента - источника военной угрозы. Объектом угрозы и атак выступают отдельные люди, страны, Евросоюз, например: 
1. Trump droht Erdogan [6].

2. Trump droht dem Iran [6].

3. Donald Trump droht China und Mexiko erneut mit Strafzöllen [8].

4. Donald Trump droht EU [6].

5. Trump attackiert Fußballerin Megan Rapinoe auf Twitter [6].

Использование лексем «der Krieg» - «война», «der Angriff» - «нападение» рядом с именем 45-го американского президента лишь усиливают его агрессивный настрой. Например:

1. Trump bereitet globalen Währungskrieg vor [6].

2. Donald Trump warnt iranische Führung vor Angriffen [8].

3. Trump -Hammer trifft China heftig [6]. (Журналисты вложили в руки Д. Трампа конкретное оружие, а именно, молот.)

Кроме перечисленных выше, Д.Трампу приписывают еще ряд отрицательных качеств, например:

1. Donald Trump verrät - выдает тайны [6].

2. Trump provoziert Chinas Tech-Riesen - провоцирует конфликты [6].

3. US-Präsident Trump kommentierte die Klagen mit einem zynischen Tweet. пишет циничные сообщения [7].

\section{Положительные черты.}

Немецкие журналисты не умаляют достоинств Дональда Трампа и подчеркивают, что он - человек, способный оценить по достоинству своего политического партнера. В качестве предиката с субъектом «Donald Trump» в немецкой прессе нередко встречается глагол «loben» - «хвалить». Объектом похвалы могут быть отдельные люди и целые страны, например:

1. Polen dagegen halte sich an Absprachen, lobte Trump [6].

В своих похвалах Трамп не скупится на добрые слова и превосходные степени:

1. Donald Trump lobt grandioses Verhältnis zu Angela Merkel [8].

2. US-Präsident D.Trump lobt saudischen Kronprinzen: ein Mann, der in den letzten 5 Jahren wirklich etwas getan hat. Es ist wie eine Revolution, auf 
eine sehr positive Weise. Sie haben wirklich spektakuläre Arbeit geleistet [8].

В случае необходимости Д. Трамп не только демонстрирует свое расположение к союзнику, но и покровительствует ему, берет его под защиту: Trump nahm die polnische Regierung demonstrativ in Schutz gegen Vorwürfe, dass sie die Rechtsstaatlichkeit in dem Land aushöhle [6].

Использование авторами медиатекстов таких лексических единиц как «demonstrativ», «spektakulär», многократные повторы подчеркивают, желание Д. Трампа произвести на публику наибольшее и наилучшее впечатление. Описывая его поведение на одной из встреч, авторы Focus.de отмечают: Treffen in Korea: Trump gibt sich als Problemlöser. - Трамп выдает себя за человека, способного решить все проблемы.

Наибольшее количество похвал и хороших слов президент Трамп отдает своей стране:

1. Sehr bald werden wir eine US-Flagge auf dem Mars hissen [9].

2. In seiner Rede zum Nationalfeiertag beschwört Präsident Trump die weltweite Dominanz der Vereinigten Staaten [9].

3. US-Präsident Donald Trump hat in einer Rede zum Unabhängigkeitstag die amerikanische Dominanz gepriesen [9].

\section{Балансирование на грани «хорошее-плохое».}

Журналисты немецкой прессы обращают внимание на то, что еще одной характерной чертой американского президента является непоследовательность, непредсказуемость отношения к своим коллегам. Хорошее отношение меняется на плохое и наоборот за достаточно короткий временной отрезок. Приведем несколько примеров:

1. 8.06.2019. Donald Trump verkündigt Einigung im Zollstreit mit Mexiko [8] - отношение положительное. Трамп провозгласил единодушие с Мексикой в решении вопросов по пошлинам. 
11.06.2019 Donald Trump droht China und Mexiko erneut mit Strafzöllen [8] - отношение отрицательное. Дональд Трамп вновь угрожает Китаю и Мексике штрафными пошлинами.

2. 7.06.2019. Trump ignoriert Merkel bei D-Day Gedenkfeier [6]. - отношение отрицательное. Трамп игнорирует Меркель.

28.06.2019. Trump lobt Merkel in den höchsten Tönen [6]. - отношение положительное. Трамп восхваляет Меркель.

Невозможность просчитать поступки американского президента зачастую рождает вопрос на страницах немецкой периодики «Wie soll Europa mit Donald Trump umgehen?» - Как должна вести себя Европа с Дональдом Трампом? Подобный запрос на немецком языке в Яндексе выдал 400 тысяч результатов.

Таким образом, анализ материалов немецких периодических изданий позволяет сделать следующие выводы. Немецкими СМИ сформирован определенный образ американского президента. Это образ имеет и отрицательные и положительные качества. Отрицательные качества чаще транслируются во внешнеполитическую среду, положительные качества в большей степени предназначены для своей страны и политических союзников, отношение к которым, однако, может с легкостью поменяться.

Список литературы:

1. Демьянков В.З. Политический дискурс как предмет политологической филологии/ www.philology.ru

2. Новикова Е. В., Есмурзаева Ж.Б., Марус М. Л., Шкайдерова Т.В Медиаобраз Д. Трампа в текстах немецких СМИ/ Филологические науки. Вопросы теории и практики. - Тамбов: Грамота, 2017. № 5(71): в 3-х ч. Ч. 1. - С. 130-135.

3. Пчегатлук С.К., Миклина С.А. Образ Трампа в российских и зарубежных СМИ: сравнительный анализ/ Научные труды КубГТУ. - 2018. - № 6. C.285-291.

4. РумянцевГ.И., Богаченко Н.Г. Образ Дональда Трампа в англоязычных СМИ: переводческий аспект/Постулат - 2018. - №2. 
5. Тхорик В.И, Фанян Н.Ю. Лингвокультурология и межкультурная коммуникация. Учебное пособие. Второе издание. - М.: ГИС, 2006. - 260 c.

6. https://www.focus.de (дата обращения 14.08.2019).

7. https://www.spiegel.de (дата обращения:14.08.2019)

8. http://www.zeit.de (дата обращения: 14.08.2019).

9. https://www.welt.de (дата обращения: 14.08.2019) References:

1. Demyankov V. Z. Political Discourse as a Subject of Political Philology/ www.philology.ru

2. Novikova E. V., Esmurzaeva J. B., Marus M. L., Shkaiderova T. V. D. Trump's Media Image in the Texts of the German Media/ Philological Sciences. Theory and practice. - Tambov: Diploma, 2017. № 5(71): in 3 hours -Part 1. - C. 130-135.

3. Pongalur S. K. Miklin S. A. Image of Trump in Russian and Foreign Media: Comparative Analysis/ Proceedings of the Kuban State University. - 2018. № 6. - P. 285-291.

4. Rumyantsev.I., Bogachenko N. G. Image of Donald Trump in the English Media: Translation Aspect/Postulate - 2018. - №2.

5. Thorik V. I., Fanyan N. Yu. Linguoculturology and Intercultural Communication. Textbook. Second edition. - M.: GIS, 2006. 260 PP.

6. https://www.focus.de (accessed 14.08.2019).

7. https://www.spiegel.de (date accessed:14.08.2019)

8. http://www.zeit.de (date accessed: 14.08.2019).

9. https://www.welt.de (date accessed: 14.08.2019) 